Maxwell, Alexander. "Blomqvist, Anders E. B. 2014. Economic Nationalizing in the Ethnic Borderlands of Hungary and Romania: Inclusion, Exclusion, and Annihilation in Szatmár/Satu Mare 1867-1944 (Ph.D.

Dissertation). Stockholm: Stockholm University. 400 pp." Hungarian Cultural Studies. e-Journal of the American Hungarian Educators Association, Volume 8 (2015): http://ahea.pitt.edu DOI: 10.5195/ahea.2015.198

\title{
Blomqvist, Anders E. B. 2014. Economic Nationalizing in the Ethnic Borderlands of Hungary and Romania: Inclusion, Exclusion, and Annihilation in Szatmár/Satu Mare 1867-1944 (Ph.D. Dissertation). Stockholm: Stockholm University. 400 pp.
}

\section{Reviewed by Alexander Maxwell}

Anders Blomqvist's doctoral dissertation examines nationalization, national conflict and national indifference in Szatmár/Satu Mare, a town once part of the Kingdom of Hungary but now just inside Romania near the Romanian-Hungarian frontier. Chronologically, the study runs from the 1867 Ausgleich to the Holocaust, placing Hungary's partition with the Treaty of Trianon more or less at the center of the narrative. Studies of nationalist politics within a single city are quite the fashion in recent years, but Blomqvist differentiates his work by emphasizing the economic motives and consequences of such politics. The prose and structure of Blomqvist's thesis leave something to be desired, but the research is solid, drawing on a wide variety of sources; his arguments, furthermore, are mostly persuasive.

The book has eleven chapters, each made up of several numbered sub-sections. Apart from the book's introduction and conclusion, the final sub-section of each chapter recapitulates the chapter as "Conclusions," in which Blomqvist sometimes talks up his contribution in an unfitting way. Reading each chapter's entire text as a reviewer proved repetitive; researchers, however, can choose either to get the gist of a chapter from the mostly footnote-free conclusions, or to read the chapter's actual content and then skip its concluding sub-section. The chapters, in turn, are grouped into five larger parts: an introduction at the front, a conclusion at the end, and in the middle three chronologically-arranged parts on dualist Hungary (Chapters Two to Four), interwar Romania (Chapters Five to Eight), and the Second World War (Chapters Nine and Ten) Assimilationist policies dominate the first two-thirds of the narrative, which is admirably documented during the interwar period in particular. When Blomqvist reaches the Second World War, the level of detail declines, the Romanian-Hungarian conflict recedes, and the expropriation of Jews becomes the dominant issue. Some of the gaps in Blomqvist's final chapter, and particularly the laconic eighth sub-section on "Romanian Reciprocity" (378-379), incidentally, are covered in Holly Case's excellent 2009 study of wartime Transylvania, Between States - The Transylvanian Question and the European Idea during World War II (Stanford University Press).

Blomqvist uses the economic emphasis of his dissertation to promote ethnic tolerance. He argues, for instance, that discriminatory assimilationist policies harm the economy. While Blomqvist does not sugarcoat the injustice of national chauvinism, his primary goal is to demonstrate its economic cost. Forced Magyarization, for example, caused "ethnic bifurcation, with high state expenditure coupled with relatively slow economic progress" (157), and interwar Romanization similarly led to "increased ethnic division and exclusion coupled with less

(cc) $\mathrm{Br}$

ULIS D-Serle
New articles in this journal are licensed under a Creative Commons Attribution 4.0 International License.

This journal is published by the University Library System of the University of Pittsburgh as part of its D-Scribe Digital Publishing Program and is cosponsored by the University of Pittsburgh Press 
Maxwell, Alexander. "Blomqvist, Anders E. B. 2014. Economic Nationalizing in the Ethnic Borderlands of Hungary and Romania: Inclusion, Exclusion, and Annihilation in Szatmár/Satu Mare 1867-1944 (Ph.D.

favorable conditions for economic growth" (278). Blomqvist even views the Holocaust through an economic lens: the expropriation and deportation of Jews were "not only a disaster for the Jews themselves, but also for the [sic] Hungarian society in general, which lost competencies, experience and know-how in an irreversible process. The deportations of the Jews did not improve the living standards of the Hungarians" (382). The book, dedicated in part to "the future of my children in a tolerant Europe," reflects Blomqvist's evident commitment to the greater European project both in its preoccupation with prosperity and in its conspicuous evenhandedness regarding ethnic disputes.

While the book's fundamental argument rests on relatively suprapersonal economic indicators, the individual chapters contain detailed information about prominent individuals and institutions. Both Hungarian Prime Minister Count Mihály Károly and the influential politician and historian Oszkár Jászi came from the Szatmár/Satu Mare region; Blomqvist describes how their national activities played out at the local level. He follows several other prominent civic leaders and politicians, including Vasile Lucaciu and Aurél Papp / Aurel Popp, showing how they responded to changing political circumstances. He also sketches how state policies influenced civic or non-governmental institutions, including schools, trade unions, churches, banks and private companies. Blomqvist's narrative ranges widely as he adduces a pleasing diversity of evidence to make his case.

Insofar as the book is a study of nationalism, Blomqvist takes his theoretical apparatus from Roger Brubaker's 2006 sophisticated and persuasive study, Ethnicity without Groups. Brubaker's theories are more often cited than understood; but Blomqvist has successfully applied them, and in this sense offers a model for postgraduate students struggling with Brubaker's ideas. Blomqvist shows how leading politicians invoked national interest to amass political capital and how individual citizens responded to elite concerns to pursue their own ends; indeed, the most interesting sub-sections of the book examine attempts to Romanianize the city's banks and factories (246-262). Complying with the letter of Romanianization laws, Hungarians and Jews hired Romanian managers, created nominal shell companies with Romanian boards of directors, and so forth.

Blomqvist has, in short, written a solid study with much interest for researchers of dualist Hungary and interwar Romania. His thesis is well documented, well theorized and free of nationalist cant. Despite the book's many virtues, its poor writing makes it unsuitable for classroom use. The problem lies less with straightforward grammatical errors as with dull prose: Blomqvist lacks an ear for vivid phrases. Six of seven sentences in a sample paragraph on page 341 , for example, use "to be" as the main verb; and the paragraph's final sentence begins: "This is evidenced by the fact that...." I fear this book would put undergraduates to sleep, and even the attention of postgraduates might flag. 